\title{
Zika Virus and Vector Transportation: A Forgotten Issue in Travel Medicine
}

\author{
Viroj Wiwanitkit ${ }^{1,2,3,4^{*}}$ \\ 'Public Health Curriculum, Surin Rajabhat University, Thailand \\ ${ }^{2}$ Hainan Medical University, China \\ ${ }^{3}$ Faculty of Medicine, University of Nis, Serbia \\ ${ }^{4}$ Joseph Ayobabalola University, Nigeria
}

Corresponding Author: Viroj Wiwanitkit, Professor, Public Health Curriculum, Surin Rajabhat University, Thailand. Email:wviroj@yahoo.com

Received July 26, 2017; Accepted August 1, 2017; Online Published August 16, 2017

Citation: Wiwanitkit V. Zika virus and vector transportation: a forgotten issue in travel medicine. Int J Travel Med Glob Health. 2017;5(3):72-73. doi:10.15171/ijtmgh.2017.15.

$\mathrm{N}$ ew emerging diseases usually pose big problems in medicine. At present, the Zika virus is a global public health problem attacking more than 50 countries around the world. The disease can cause dengue-like clinical problems and induce neurological abnormalities and congenital syndromes in some cases. ${ }^{1}$ From its first outbreak, the Zika infection has occurred around the world and has become the focus issue of today's public health. McCloskey and Endericks noted that response to the Zika virus outbreak was an international issue and could be a lesson for future outbreaks. ${ }^{2}$ The movement of the disease from one setting to another is a very interesting phenomenon.

Zika infection already occurs worldwide, and travel is usually mentioned in relation to the spread of disease. Human travel is usually mentioned in relation to the disease migrating from an endemic setting to a new setting causing an emerging infectious disease outbreak. The greatest concern is usually given to mass gathering events, such as the Olympic Games ${ }^{3-5}$ and Hajj. ${ }^{6,7}$ Nevertheless, the regular maintenance for disease surveillance is necessary. Tunali and Turgay ${ }^{8}$ mentioned that traveling is an important way in which disease can be transmitted from one area to another. They further stated that traveling was an important cause of the migration of the Zika virus to new settings and that international traveling could cause the migration of infectious diseases from developing countries to other regions; exotic travelers who have an exotic travel style are at an increased risk. Díaz-Menéndez et al found that travelers to endemic areas usually seek information about the risk of acquiring infectious diseases before traveling." Undoubtedly, the Zika virus is already known worldwide, and travel medicine clinics can be expected to be prepared for consultation and the promotion of safe travel and disease prevention during travel.

Certainly, several cases of Zika virus infection have already been imported to new settings by travelers. Katanami et al suggested that a good disease surveillance system be established to prevent the importation of diseases from other areas. ${ }^{10}$ In general, the recommendation is usually to include the Zika virus infection "in the differential diagnosis, especially in febrile patients with a rash returning from an endemic area." ${ }^{11}$ In fact, control and screening should be implemented at any international port and should focus on any direction of travel. Wiwanitkit noted that the infected case might be a traveler from either an endemic or a non-endemic area, and the traveler returning to an endemic area might carry the disease from other areas. ${ }^{12}$

Nevertheless, a usually forgotten issue is the travel of the vector of the disease. In this short editorial, the specific issues of vector importation and its relation to disease migration and occurrences in new settings are discussed. Although there are many methods for controlling disease migration, most usually focus on the migration of human hosts; very few methods are applied for vector control. Despite some attempts to control vector transportation, the occurrence of vectors in a transportation vehicle is still observable. Although disinfection might be applied, this method has proven to be ineffective in managing the problem of vector existence in international transportation vehicles..$^{13}$ Due to the high volume of international transportation in the present day, the migration of disease due to vector transportation can be expected. This is a really interesting but forgotten issue in travel medicine.

Copyright $(\subset 2017$ The Author(s). This is an open-access article distributed under the terms of the Creative Commons Attribution License (http:// creativecommons.org/licenses/by/4.0), which permits unrestricted use, distribution, and reproduction in any medium, provided the original work is properly cited. 


\section{Conflict of Interest Disclosures}

None.

\section{Ethical Approval}

Not applicable.

\section{Funding/Support}

There was not funding support for this research.

\section{References}

1. Joob B, Wiwanitkit V. Zika virus infection and dengue: A new problem in diagnosis in a dengue-endemic area. Ann Trop Med Public Health. 2015;8(4):145-146. doi:10.4103/17556783.162402 .

2. McCloskey B, Endericks T. The rise of Zika infection and microcephaly: what can we learn from a public health emergency? Public Health. 2017;150:87-92. doi:10.1016/j.puhe.2017.05.008.

3. Wiwanitkit V. Zika virus infection and the Olympic Games 2016. Rev Clin Esp. 2017;217(3):178-179. doi:10.1016/j. rce.2016.12.005.

4. Vancini RL, Andrade MS, Vancini-Campanharo CR, Barbosa de Lira CA. Zika virus infection, summer Olympic and Paralympic Games in Rio 2016, and sports performance. J Hum Kinet. 2016;53:5-7. doi:10.1515/hukin-2016-0005.

5. Warnke K, Paul J. Zika Virus - Impact on the 2016 Olympic Games in Rio de Janeiro. Sportverletz Sportschaden. 2016;30(3):154-156. doi:10.1055/s-0042-110251.

6. Ahmed QA, Kattan RF, Memish ZA. Hajj 2016: Under the shadow of global Zika spread. Am J Infect Control. 2016;44(12):14491450. doi:10.1016/j.ajic.2016.09.002.

7. Al-Tawfiq JA, Gautret P, Benkouiten S, Memish ZA. Mass gatherings and the spread of respiratory infections. Lessons from the Hajj. Ann Am Thorac Soc. 2016;13(6):759-765. doi:10.1513/ AnnalsATS.201511-772FR.

8. Tunali V, Turgay $\mathrm{N}$. The Concept of travel medicine and the actual situation of travel-related illnesses. Turkiye Parazitol Derg. 2017;41(2):114-118. doi:10.5152/tpd.2017.5213.

9. Díaz-Menéndez $M$, de la Calle-Prieto $F$, Arsuaga $M$, et al. Hotline for Zika virus: experience of a tropical and travel medicine unit. Gac Sanit. 2017. doi:10.1016/j.gaceta.2017.04.003.

10. Katanami Y, Kutsuna S, Taniguchi S, et al. Detection of Zika virus in a traveller from Vietnam to Japan. J Travel Med. 2017;24(5). doi:10.1093/jtm/tax031.

11. Summers DJ, Acosta RW, Acosta AM. Zika virus in an American recreational traveler. J Travel Med. 2015;22(5):338-340. doi:10.1111/jtm.12208.

12. Wiwanitkit V. Zika virus infection among travelers departing from Thailand. Ann Trop Med Public Health. 2016;9(6):415. doi:10.4103/1755-6783.193950.

13. Mier-Y-Teran-Romero L, Tatem AJ, Johansson MA. Mosquitoes on a plane: Disinsection will not stop the spread of vectorborne pathogens, a simulation study. PLoS Negl Trop Dis. 2017;11(7):e0005683. doi:10.1371/journal.pntd.0005683. 